SIR,

The surging advance of Bering Glacier, Alaska, U.S.A.:

a progress report

\section{EARLY ACTIVITY}

In early June 1993, we determined that accelerated ice flow was spreading from the main Bering Glacier trunk to the upper piedmont lobe and that an incipient surge was in progress (Muller and others, 1993). U.S.G.S. aerial photographs taken in March 1993 bear no evidence of this abrupt change in regime, which interrupts a general down-wasting and retreat that has persisted since 1968. Ice-front advance currently in progress substantiates the hypothesis of a 20-30 year surge cycle suggested by Post (1972).

Bering Glacier, the largest alpine glacier known to surge, descends to a coastal lowland from the Chugach Range where it is nourished by the Bagley Ice Field. The Bering Glacier trunk flows past Override Ridge, a reference landmark for thickening ice, that has in the past signaled developing surge conditions, and the western Grindle Hills as it leaves the mountains and spreads to join Steller Glacier (Fig. 1). Together, they comprise the largest known glacier system in North America $\left(5173 \mathrm{~km}^{2}\right)$ and form a piedmont lobe second only in size to that of Malaspina Glacier, $150 \mathrm{~km}$ to the east.

The piedmont lobe fronts in Tsivat and Tsiu Lakes on its eastern margin and Vitus Lake to the south (Fig. 2). Bordering the southern Grindle Hills, Tsivat Sublobe occupies Tsivat Lake Basin northeast of Weeping Peat and Peat Falls Islands, which separate Tsivat and Tsiu Lakes. Bentwood Island lies between Tsiu and Vitus Lakes. The glacier remained in contact with Peat Falls Island at the western shore of Tsiu Lake until the island was entirely over-ridden in January 1994. Other foreland land masses and lake basins uncovered by ice recession between 1978 and 1993 (Muller and Fleisher, 1995) are currently being re-occupied as Bering Glacier continues to press forward.

\section{SURGE-INDUCED DEFORMATION}

By mid-summer 1993, 6 weeks after the surge began, extensive doming had spread to the central piedmont area 6-8 km down-glacier from the Grindle Hills, transforming previously smooth and gentle slopes into widely spaced, extensively broken, irregular undulations. By 23 August, ice in "a $5 \mathrm{~km}$ wide tongue of the central terminus" was reported to be advancing into Vitus Lake at a rate of $100 \mathrm{~m} \mathrm{~d}^{-1}$ (Molnia, 1994). Surging advance of the bulging ice front along the eastern ice margin began in early to mid September. By November, the piedmont lobe contained heavily crevassed, bulging domes tens of meters in relief and areas of conjugate rectangular crevasse systems expanded as accelerated ice movement steadily spread toward the glacier margin. Virtually the entire piedmont lobe had thickened conspicuously and accelerated calving into Lake Vitus spawned a great quantity of brash ice, bergy bits and icebergs (Lingle and others, 1993; Molnia, 1993). All but the easternmost basin of Lake Vitus was choked with icebergs.

In contrast to the southern Lake Vitus border, the eastern margin consisted of alternating land and lake basins. By mid-September 1993, the ice front had advanced on to Tsitus Island at the eastern end of Lake Vitus and constricted the Tsiu Lake outlet at Bentwood Narrows (Fig. 2). West of Tsiu Lake, the ice front thickened on Peat Falls Island and, by mid-October, a massive dome of heavily crevassed ice had ridden up its stoss side. Ice was shoved on to the western shore of Weeping Peat Island in a broken wall $20-30 \mathrm{~m}$ high. Stacked thrust plates appeared to account for icemarginal thickening (Fleisher and others, 1994).

Less than $100 \mathrm{~d}$ into the surge, the Bentwood Narrows outlet channel, around the west end of Bentwood Island, opened by retreat in August 1989,

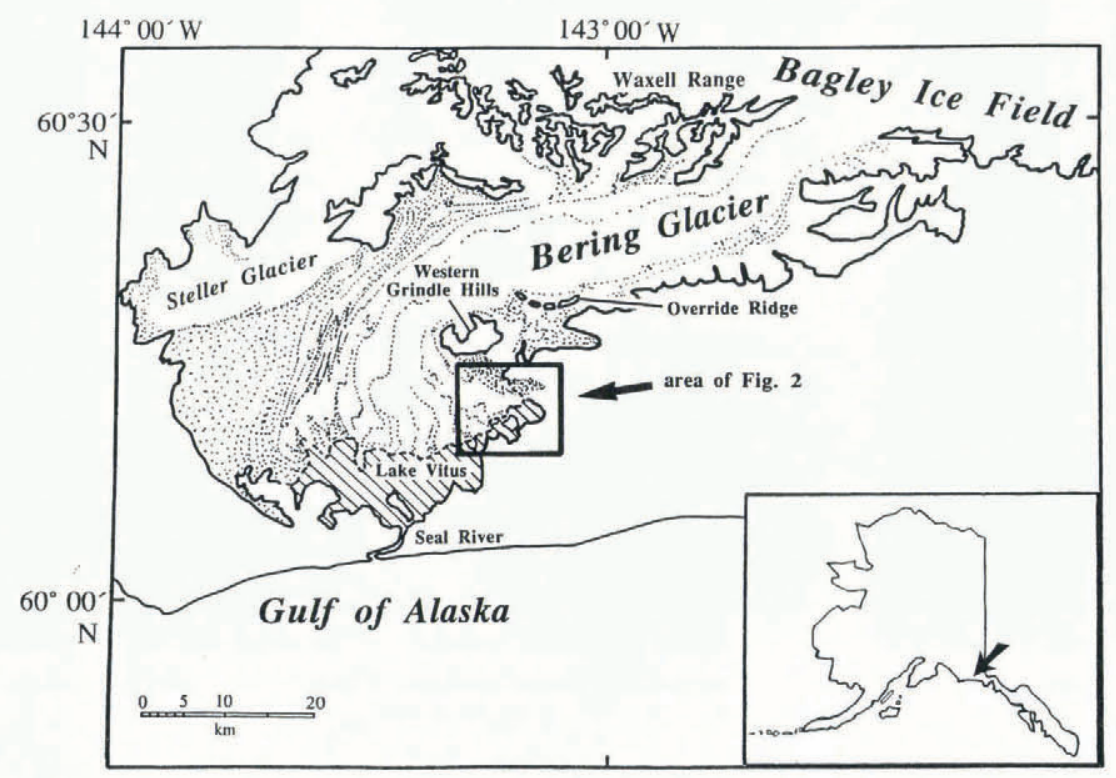

Fig. 1. Index map. Bering Glacier and related geographic features. 


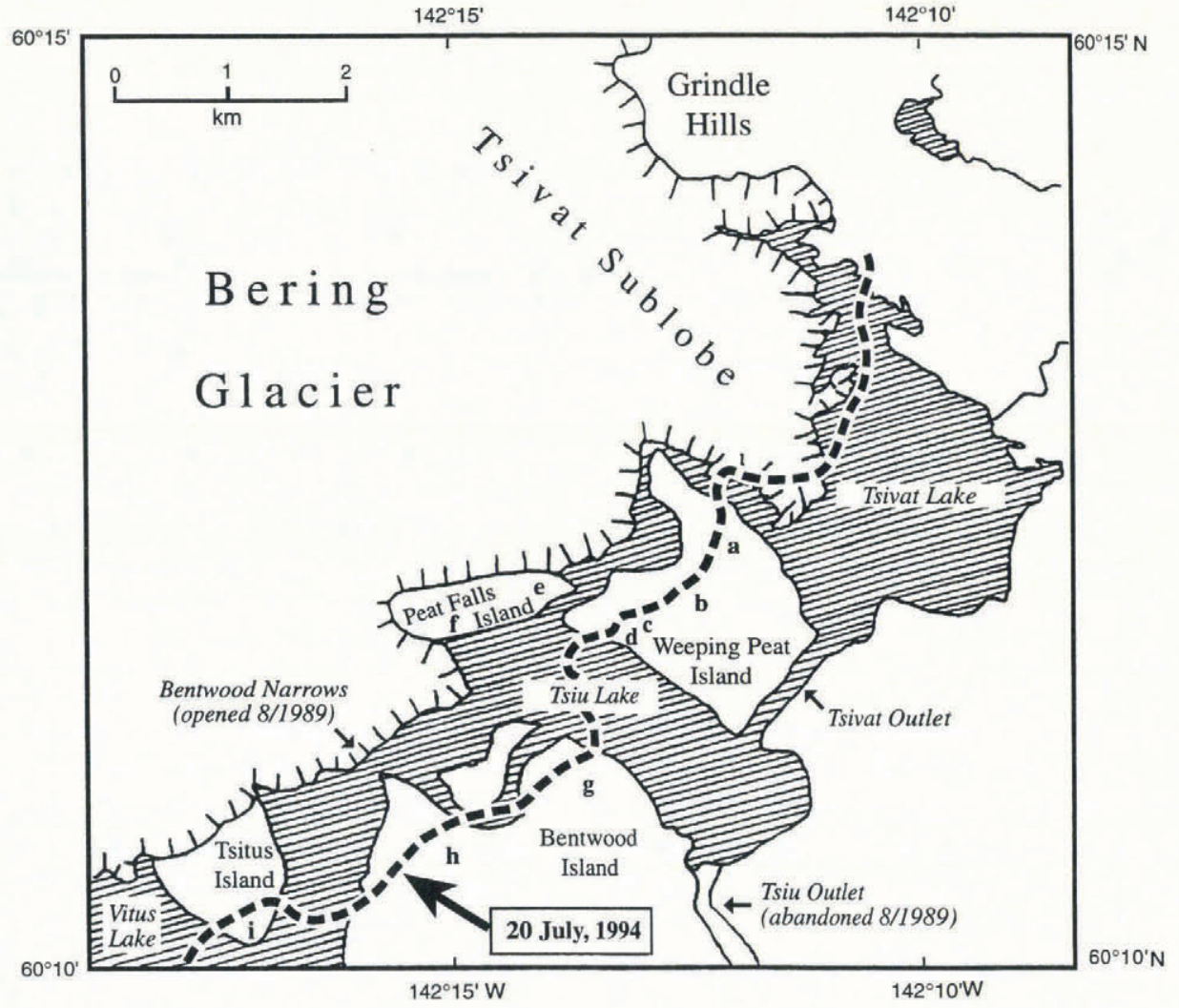

Fig. 2. Eastern Bering Glacier Piedmont Lobe. The eastern foreland, as seen prior to surge, consists of Tsivat and Tsiu Lakes, separated by Weeping Peat Island. Bentwood Island shares its western shore with Vitus Lake. Surface reference locations from which movement data were collected (see Table 1) are identified by letters a-i (after Muller and Fleisher, in press). Dashed line shows position of ice margin on 20 July 1994.

was once again dammed, raising the level of Tsiu Lake by $9-10 \mathrm{~m}$ and inundating foreland low areas. By early November 1993, the ice margin had advanced several hundred meters, mounting the island with a steep ice front $15-20 \mathrm{~m}$ high.

By the year's end, virtually all of Peat Falls Island was covered and ice occupied the entire western part of Weeping Peat Island. Tsiu Lake appeared to have stabilized at a level $2-3 \mathrm{~m}$ below its highest pre-surge strandline (Fleisher and others, 1990), a net rise of 14 $15 \mathrm{~m}$. Contrasting with this aggressive initial advance was the retarded activity of Tsivat Sublobe that remained relatively dormant until early 1994 when an open mosaic of grounded ice islands was dislodged and compressed eastward $230 \mathrm{~m}$ into Tsivat Lake. At this time, the piedmont lobe contained conspicuous linear zones of en echélon crevasses aligned parallel to flow and situated at what appeared to be the boundaries of discrete "ice streams" (Fig. 3). Fluctuations in ice-stream activity may partially account for observed temporal variations in movement at the ice front. A mid-February 1994 overview of the eastern ice margin and foreplain is shown in Figure 4.

In early summer 1994, the main surge activity was at the southern ice margin, where advancing ice and compressed icebergs virtually filled the vestige of Lake Vitus. Ice-penetrating radar profiles of the upper Bering Glacier trunk and Bagley Ice Field in June 1994 indicated that extensive up-glacier surface deformation was widespread, and that the entire Bering Glacier and its source area were involved in this cyclic recurrence of major surging (Arcone and others, 1994).

\section{ICE-FRONT MOVEMENT}

An archive collection of photographs taken at 8-20 week intervals from four surface-survey stations on Weeping Peat and Peat Falls Islands (Fig. 2) documents detailed changes during the initial 6 months of the surge from early June to late November 1993. Figure 5 illustrates the magnitude of changes that occurred at our Base Camp photographic survey station on Weeping Peat Island between June and November 1993.

Table 1 contains measurements of ice movement along the eastern margin taken from several generations of U.S.G.S. aerial photographs (July, September and November 1993) and supplemented by oblique $35 \mathrm{~mm}$ aerial coverage in January and February 1994. These data indicate that surge energy reached different parts of the ice margin at different times. Ice advance on Peat Falls Island began in September, whereas simultaneous retreat was still in progress at Bentwood Narrows and on Tsitus Island. No significant changes were noted on the Tsivat Sublobe until November. Not only have the ensuing rates of advance differed from one location to another but they have also varied with time.

The highest rates of ice-front advance at several stations occurred between September and November 1993, when on Peat Falls Island the rate of advance 


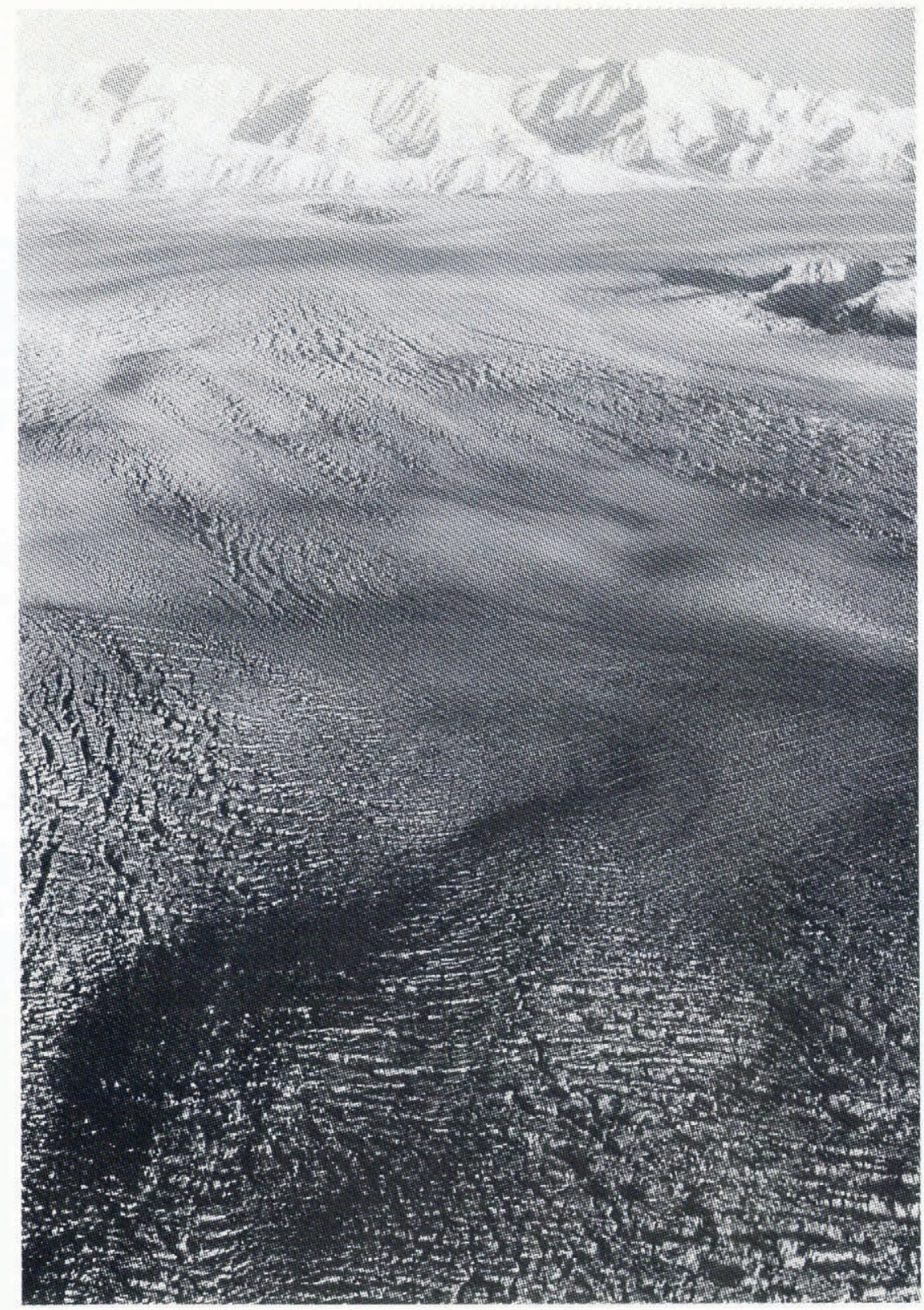

Fig. 3. Linear zones of en echélon crevasses. The orientation of these fractures parallels the tensional direction associated with displacement along shear planes, which separate ice streams of differential velocity.

increased to $7.4 \mathrm{~m} \mathrm{~d}^{-1}$, then declined to $4.3 \mathrm{~m} \mathrm{~d}^{-1}$ in early 1994, when the island was entirely over-ridden. Similarly, rates increased to a high of $6.7 \mathrm{md}^{-1}$ on Bentwood Narrows and Tsitus Island during the fall of 1993. On Weeping Peat Island, rates fluctuated throughout the fall and into February 1994 but not systematically or uniformly. Since then, a general slowing has occurred, while slight increases were noted on Bentwood Narrows and Tsitus Island.

Advance on the eastern foreplain generally slowed into early summer 1994. Data collected at six surface survey stations (Fig. 2) throughout June, and later spotchecked in July, are summarized by histograms in Figure 6 . The most complete record was obtained at Bentwood East, where measurements were made at $4 \mathrm{~d}$ intervals during $16 \mathrm{~d}$ from 6 to 22 June, then again on 20 July. Here, rates of advance increased steadily from 1.47 to $2.55 \mathrm{~m} \mathrm{~d}^{-1}$ between 6 and 11 June, then declined gradually to $1.23 \mathrm{md}^{-1}$ by 22 June. Measurement on
20 July yielded a $28 \mathrm{~d}$ cumulative rate of $1.02 \mathrm{~m} \mathrm{~d}^{-1}$. This progressive increase, followed by gradual decline, might imply cyclic fluctuation on a $30 \mathrm{~d}$ wavelength, with data from 20 July falling on the declining side of a second cycle. Although cyclic change may have occurred, there are too little data to support such an interpretation. Rates calculated from three measurements at Bentwood West are consistent with those from Bentwood East during the same time period. Advance slowed from a maximum of 2.20 to a minimum of $1.56 \mathrm{md}^{-1}$ between 10 and 22 June, and declined further to a cumulative rate of $0.42 \mathrm{~m} \mathrm{~d}^{-1}$ in July, which is less than half that for Bentwood East.

Of the four survey stations on Weeping Peat Island, the most continuous, detailed record of movement was obtained at Riverhead Station. Here, rates gradually increase from 0.19 in early June to a high of $2.97 \mathrm{~m} \mathrm{~d}^{-1}$ in mid-June, then decreased to $1.48 \mathrm{~m} \mathrm{~d}^{-1}$ by 21 June. This $16 \mathrm{~d}$ rise and decline matches the changes at Bentwood 


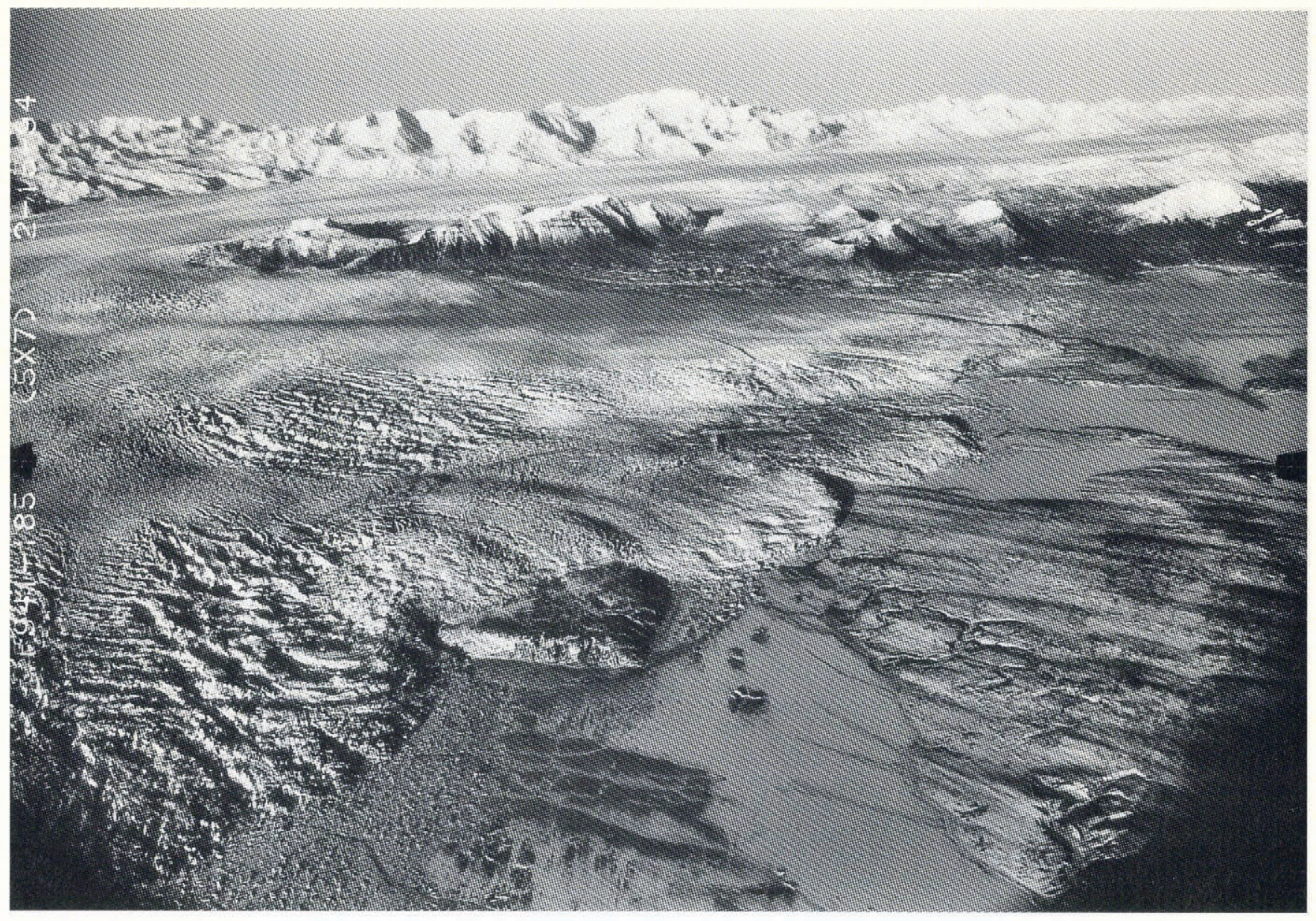

Fig. 4. Eastern ice margin and foreplain (photograph by courtesy of Austin Post). This 15 February 1994 photograph shows Bering Glacier advancing on to islands and into lake basins of the eastern foreplain. The Bering Glacier trunk flows between the snow-capped Grindle Hills in the middle ground and the Waxwell Range on the horizon.

East. Although based on only three data points, the histogram for North Ridge shows progressive acceleration from $0.46 \mathrm{~m} \mathrm{~d}^{-1}$ in early June to a maximum of $2.05 \mathrm{~m} \mathrm{~d}^{-1}$ by 10 June, the last day movement was measured here. This acceleration is similar to that seen at Riverhead and Bentwood East during the same time interval. Middle Ridge is the only survey station at which a short-term, abrupt change in rate ("jerky" activity) may have occurred. An initial low rate during a $9 \mathrm{~d}$ period (5-14 June) was abruptly interrupted by a $1 \mathrm{~d}$ accelerated increase to a rate of $1.39 \mathrm{~m} \mathrm{~d}^{-1}$, which then returned to a slow $0.20 \mathrm{~m} \mathrm{~d}^{-1}$ that persists from 15 to 21 June. The cumulative average for late June through mid-July increased to $0.38 \mathrm{md}^{-1}$, which is less than the late-June rate for South Ridge and Riverhead. The apparent spike of activity on 15 June may not have resulted from jerky surging advance. Instead, it is likely to have been produced by the collapse and forward sliding of a protruding basal thrust plate, a process commonly observed along the eastern foreland ice front. Rates measured at South Ridge were the most uniform for the eastern ice front, consisting of a slight increase from $1.08 \mathrm{~m} \mathrm{~d}^{-1}$ in early June that reached $1.70 \mathrm{~m} \mathrm{~d}^{-1}$ by midJune, then declined to $1.36-1.40 \mathrm{~m} \mathrm{~d}^{-1}$ during the last $8 \mathrm{~d}$ of data collection. This consistent rate of movement is unlike that observed elsewhere, perhaps due to the local influence of ice-flow adjustment to the adjacent Tsiu Basin.

\section{SUMMARY COMMENTS}

Twenty-five years of rapid retreat ended in the early summer of 1993, when a pulse of accelerated ice flow moved swiftly down-glacier and spread into the Bering Glacier piedmont lobe. Rapid mid-summer ice flow, with intense crevassing over surface domes, led to ice-front advance at rates that ranged from 2.1 to $7.4 \mathrm{~m} \mathrm{~d}^{-1}$ along the eastern ice margin through late fall. Here, the advance generally slowed in late winter and early spring, and by June 1994 had diminished by $50-75 \%$, whereas activity remained vigorous along the southern Vitus Lake ice front. The cumulative, surge-related displacement of Bering Glacier along the eastern foreplain ice margin during a 1 year period (July 1993July 1994) is illustrated in Figure 2. Expanding surface deformation up-glacier and beneath the snowpack of Bagley Ice Field indicates that the entire Bering Glacier is involved and that a major surge is in progress.

Notable variation in rates of advance from place to place, and fluctuations in rate with time throughout 1993-94, suggest the combined influence of several factors, each of which remains to be evaluated thoroughly. These include how subglacial topography controls direction and rate of flow, the mode of ice failure under compressive stress within the piedmont lobe and the influence of englacial and subglacial water on ice deformation during surge activity. 
a

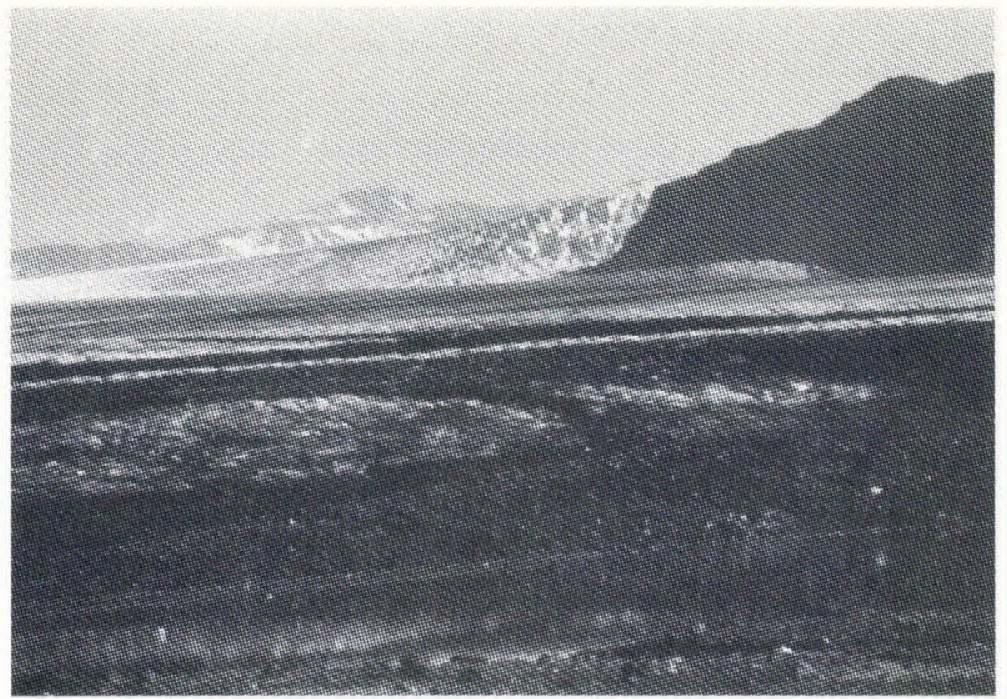

b

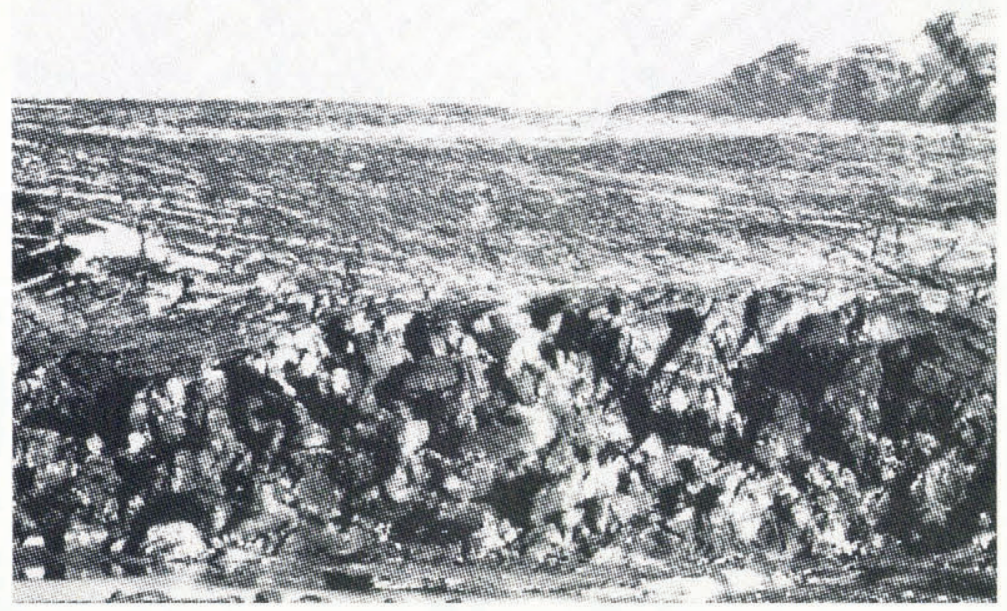

c

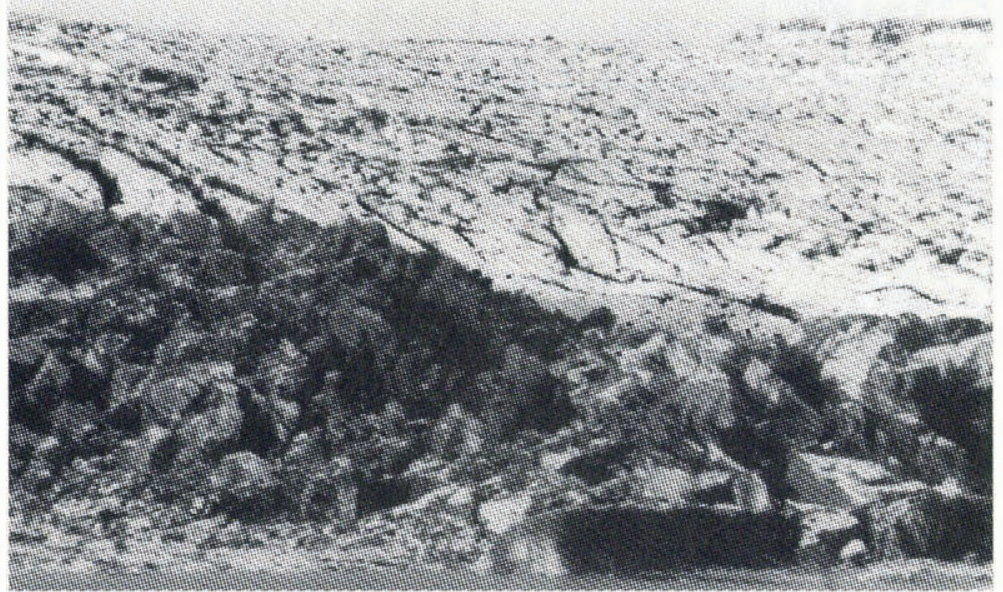

Fig. 5. Weeping Peat Island Base Camp photographic survey station. Three increments of progressive advance shown in a semi-continuous, time-lapse photographic record during a 6 month period from June to November 1993. (a) 4 June 1993 shows pre-surge conditions, when supraglacial debris marked the ice front in an arm of Tsui Lake. (b) 19 October 1993 and (c) 21 November 1993 show changes due to progressive advance and ice thickening. This photographic station was overridden in late March 1994. 


\begin{tabular}{|c|c|c|c|c|c|c|c|}
\hline \multirow{2}{*}{$\begin{array}{l}\text { Map } \\
\text { reference } \\
\text { point }\end{array}$} & \multirow[t]{2}{*}{ Location } & \multicolumn{6}{|c|}{ Meters of change and rates of advance $\left(\mathrm{m} \mathrm{d}^{-1}\right)$} \\
\hline & & $\begin{array}{cc}\text { From } & 14 / 6 / 93 \\
\text { To } & 10 / 7 / 93\end{array}$ & $\begin{array}{l}10 / 7 / 93 \\
10 / 9 / 93\end{array}$ & $\begin{array}{l}10 / 9 / 93 \\
17 / 11 / 93\end{array}$ & $\begin{array}{l}17 / 11 / 93 \\
3 / 1 / 94\end{array}$ & $\begin{array}{l}3 / 1 / 94 \\
25 / 2 / 94\end{array}$ & $\begin{array}{l}25 / 2 / 94 \\
5 / 6 / 94\end{array}$ \\
\hline & $\begin{array}{l}\text { Weeping Peat Island } \\
\text { North Ridge }\end{array}$ & $\mathrm{N} / \mathrm{C}$ & $+300(49)$ & $+350(52)$ & $+100(21)$ & $+350(66)$ & +150 \\
\hline $\mathrm{b}$ & Middle Ridge & $\mathrm{N} / \mathrm{C}$ & $+350(5.7)$ & $+200(2.9)$ & $+200(4.3)$ & $+200(3.8)$ & $+100(1.0)$ \\
\hline c & Riverhead & $\mathrm{N} / \mathrm{D}$ & $\mathrm{N} / \mathrm{D}$ & $\mathrm{N} / \mathrm{D}$ & $\mathrm{N} / \mathrm{D}$ & $\mathrm{N} / \mathrm{D}$ & $\mathrm{N} / \mathrm{D}$ \\
\hline d & South Ridge & $\mathrm{N} / \mathrm{C}$ & $+300(4.9)$ & $+400(5.9)$ & $+200(4.3)$ & $+250(4.7)$ & $+400(4.0)$ \\
\hline $\begin{array}{l}e \\
f\end{array}$ & $\begin{array}{l}\text { Peat Falls Island } \\
\text { East } \\
\text { West }\end{array}$ & $\begin{array}{l}\mathrm{N} / \mathrm{C} \\
\mathrm{N} / \mathrm{C}\end{array}$ & $\begin{array}{l}+200(3.2) \\
+100(1.6)\end{array}$ & $\begin{array}{l}+500(7.4) \\
+200(2.9)\end{array}$ & $\begin{array}{l}+200(4.3) \\
+250(5.3)\end{array}$ & $\begin{array}{l}\mathrm{O} / \mathrm{R} \\
\mathrm{O} / \mathrm{R}\end{array}$ & $\begin{array}{l}\mathrm{O} / \mathrm{R} \\
\mathrm{O} / \mathrm{R}\end{array}$ \\
\hline $\begin{array}{l}\mathrm{g} \\
\mathrm{h}\end{array}$ & $\begin{array}{l}\text { Bentwood Island } \\
\text { East } \\
\text { West }\end{array}$ & $\begin{array}{l}\mathrm{N} / \mathrm{D} \\
\mathrm{R}\end{array}$ & $\begin{array}{l}\mathrm{N} / \mathrm{D} \\
-50(-0.9)\end{array}$ & $\begin{array}{l}\mathrm{N} / \mathrm{D} \\
+450(6.7)\end{array}$ & $\begin{array}{l}\mathrm{N} / \mathrm{D} \\
+250(5.3)\end{array}$ & $\begin{array}{l}\mathrm{N} / \mathrm{D} \\
+150^{*}(2.8)\end{array}$ & $\begin{array}{l}\mathrm{N} / \mathrm{D} \\
+300^{*}(3.0)\end{array}$ \\
\hline $\mathrm{i}$ & Tsitus Island & $\mathrm{R}$ & $-30^{*}(-1.3)$ & $+450^{*}(6.7)$ & $+100(2.1)$ & $+150(2.8)$ & $+300(3.0)$ \\
\hline
\end{tabular}

O/R, Over-ridden. N/D, No data. N/C, No recognizable change. R, Unmeasured retreat. -, Retreat (m). +, Advance (m). *, Values determined from $35 \mathrm{~mm}$ oblique images. Map reference points are given in Figure 2.
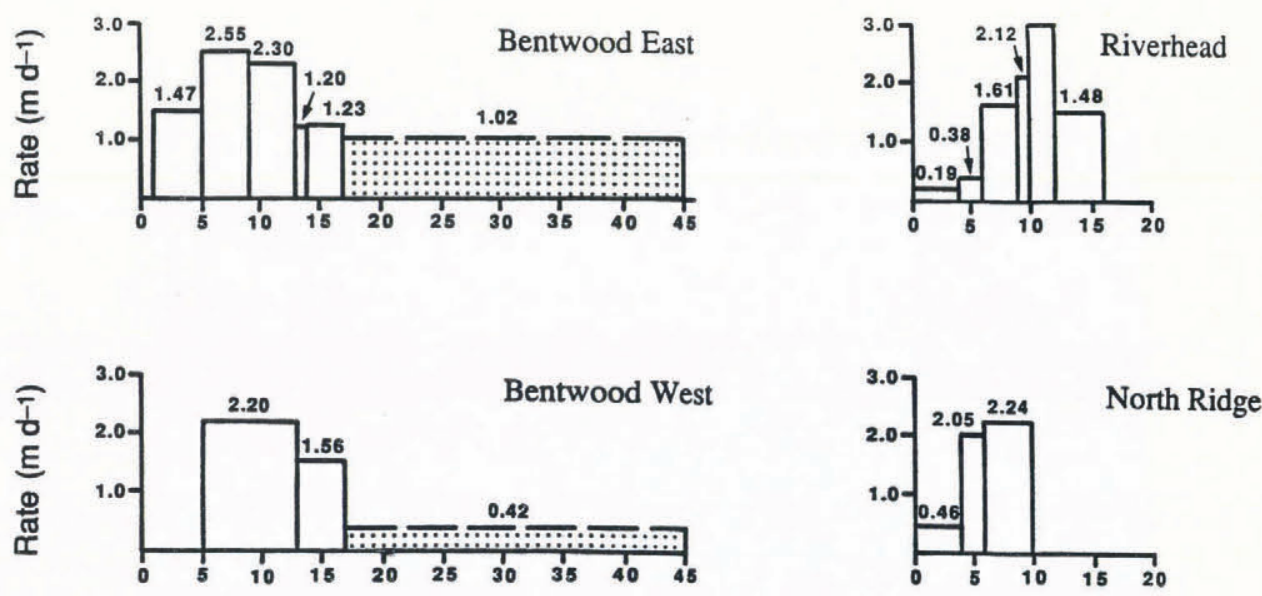

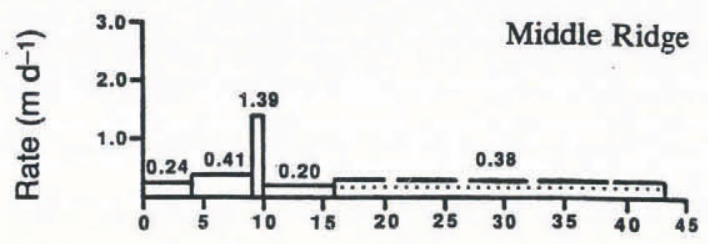

Time (d)

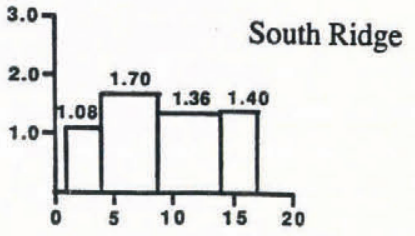

Time (d)

Fig. 6. Histograms illustrating rates of advance on Bentwood and Weeping Peat Islands, June- July 1994. Day zero coincides with 5 June 1994. Stipple pattern indicates cumulative rate for late fune to mid July 1994. 
Department of Earth Sciences, State University of New York-Oneonta, Oneonta, New Tork 13820, U.S.A.

\section{Heroy Geological Laboratory,}

E. H. MULLER

Syracuse University,

Syracuse, New rork 13244, U.S.A.

New York State Geological Survey,

3140 CEC, Albany,

New York 12230, U.S.A.

Department of Geosciences,

Oregon State University,

Corvallis, Oregon 97330, U.S.A.

\section{U.S. Army Cold Regions Research and}

Engineering Laboratory,

Hanover, New Hampshire 03755, U.S.A.

\section{Department of Earth Sciences,} State University of New York-Oneonta, Oneonta, New York 13820, U.S.A.

\section{L. ROSENFELD}

\section{September 1994}

\section{POSTSCRIPT}

Additional field work conducted during 20-23 October 1994 indicates that summer measurements of declining rates of advance (Fig. 6) did indeed signal the waning stages of surge activity along the eastern sector of the Bering Glacier piedmont lobe. End moraines, formed at the ice front on 20 July mark the maximum extent of advance on Bentwood Island (Fig. 2). Similarly, on Weeping Peat Island, a projection of the mid-July rate of advance placed a push moraine at its end position on 24
July. This was followed by rapid retreat as accelerated back-wasting degraded the highly fractured terminus. As of 21 October, $93 \mathrm{~d}$ after surging advance abated, the ice front at site a (North Ridge) had retreated $30 \mathrm{~m}$ and at site b (Middle Ridge) 20-23 m, both on Weeping Peat Island. At site g, Bentwood Island, $13 \mathrm{~m}$ of retreat were measured on 23 October 1994.

This cessation of surging advance coincides within days of an abrupt and catastrophic jökulhlaup discharge into Tsivat Lake on 27 July (Molnia and others, 1994). However, because many components of this very large and complex glacier system remain undefined, a causeand-effect relationship has not yet been established.

\section{REFERENCES}

Arcone, S. A., A.J. Delaney and P.J. Fleisher. 1994. Radar profiling of hydrologic and snow conditions in the Bagley Ice Field and Bering Glacier, Chugach Range, AK. EOS, $75(44), 64$.

Fleisher, P.J., D. H. Cadwell, E. H. Muller and D. Franzi. 1990. Downwasting of Bering Glacier as analog for New York glaciation. Abstr. Programs - Geol. Soc. Am., $22(2), 16$.

Fleisher, P.J., E. H. Muller, D. H. Cadwell, C. L. Rosenfeld, A. Post and P. K. Bailey. 1994. Monitoring the 1993 surge of the Bering Glacier, AK. Abstr. Programs -Geol. Soc. Am., $26(3), 17$.

Lingle, C. S., A. Post, U. C. Herzfeld, B. F. Molnia, R. M. Krimmel and J.J. Roush. 1993. Correspondence: Bering Glacier surge and icebergcalving mechanism at Vitus Lake, Alaska, U.S.A. J. Glaciol., 39 (133), 722-727.

Molnia, B. F. 1993. Alaskan glacier races forward. Sci. News, 144, 333.

Molnia, B. F. 1994. Bering Glacier surges into 1994. Geotimes, 39, 7.

Molnia, B.F., A. Post and P.J. Fleisher. 1994. Unusual hydrological events related to the 199394 surge of Bering Glacier, Alaska. EOS, $\mathbf{7 5}(44), 63$.

Muller, E.H. and P.J. Fleisher. 1995. Bering Glacier; surging history and potential for renewed retreat. Arct. Alp. Res., 27 (1), $81-88$.

Muller, E. H., A. Post, P.J. Fleisher, D. H. Cadwell and E. Natel. 1993. Resurgence of the Bering Glacier. Abstr. Programs Geol. Soc. Am.. $25(6), 224$.

Post, A. 1972. Periodic surge origin of folded medial moraines on Bering piedmont Glacier, Alaska. f. Glaciol., 11(62), 219226. 